\title{
Role of Calcineurin Signaling in Membrane Potential- Regulated Maturation of Cerebellar Granule Cells
}

\author{
Makoto Okazawa, ${ }^{1}$ Haruka Abe, ${ }^{1,2}$ Michiko Katsukawa, ${ }^{1}$ Kouichirou Iijima, ${ }^{1,3}$ Tatsuto Kiwada, ${ }^{1}$ and \\ Shigetada Nakanishi ${ }^{1}$ \\ ${ }^{1}$ Department of Systems Biology, Osaka Bioscience Institute, Suita, Osaka 565-0874, Japan, and ${ }^{2}$ Laboratory of Functional Biology and ${ }^{3}$ Department of \\ Molecular and System Biology, Graduate School of Biostudies, Kyoto University, Yoshida, Sakyo-ku, Kyoto 606-8501, Japan
}

At the early postnatal period, cerebellar granule cells proliferate, differentiate, migrate, and finally form refined synaptic connections with mossy fibers. During this period, the resting membrane potential of immature granule cells is relatively depolarized, but it becomes hyperpolarized in mature cells. This investigation was conducted to examine the role of this alteration in membrane potential and its downstream signaling mechanism in development and maturation of granule cells. Experiments were designed to precisely characterize the ontogenic processes of developing granule cells by combining organotypic cerebellar cultures with the specific expression of EGFP (enhanced green fluorescent protein) in granule cells by use of DNA transfection. Multiple approaches using morphology, electrophysiology, and immunohistochemistry demonstrated that granule cells developed and matured at the physiological $\mathrm{KCl}$ concentration in organotypic cultures in a temporally regulated manner. We addressed how persistent membrane depolarization influences the developmental and maturation processes of granule cells by depolarizing organotypic cultures with high $\mathrm{KCl}$. Depolarization preserved the developmental processes of granule cells up to the stage of formation of immature dendrites but prevented the maturation processes for synaptic formation by granule cells. Importantly, this blockade of the terminal maturation of granule cells was reversed by inactivation of calcineurin with its specific inhibitor. This investigation has demonstrated that alteration of the membrane potential and its downstream calcineurin signaling play a pivotal role in triggering the maturation program for the synaptic organization of postnatally developing granule cells.

\section{Introduction}

Cerebellar granule cells proliferate and become differentiated in the external granular layer (EGL) during the early postnatal period (Ramón y Cajal, 2000). Postmitotic cells then migrate inwardly into the internal granular layer (IGL) and extend branched dendrites and long axons. The multiple dendrites become mature to form a claw-like structure that encapsulates mossy fibers and refines synaptic transmission. In many neuronal cells, the resting membrane potential shifts from a relatively depolarized state to a more hyperpolarized one during development [Nakanishi and Okazawa (2006), and references therein]. The granule cell in the cerebellum is one such neuronal cell that changes its resting membrane potential during development (Rossi et al., 1998; Cathala et al., 2003). Membrane depolarization enhances calcium entry and in turn activates $\mathrm{Ca}^{2+}$ / calmodulin-dependent protein kinase (CaMK) and $\mathrm{Ca}^{2+}$ / calmodulin-dependent calcineurin phosphatase (CaN) (West et al., 2002; Gaudillière et al., 2004; Suzuki et al., 2005; Nakanishi and Okazawa, 2006; Shalizi et al., 2006). This $\mathrm{Ca}^{2+}$ signaling

Received Dec. 14, 2008; accepted Jan. 22, 2009.

This work was supported by Ministry of Education, Culture, Sports, Science, and Technology of Japan Grants KAKENHI 17002016 (S.N.) and 18790209 (M.0.) and by grants from the Takeda Science Foundation and the Suntory Institute for Bioorganic Research. We thank Astellas Pharma for the supply of FK506.

Correspondence should be addressed to Shigetada Nakanishi, Osaka Bioscience Institute, 6-2-4, Furuedai, Suita, Osaka 565-0874, Japan. E-mail: snakanis@obi.or.jp.

D01:10.1523/JNEUROSCI.5932-08.2009

Copyright $\odot 2009$ Society for Neuroscience $\quad$ 0270-6474/09/292938-10\$15.00/0 should greatly influence intracellular signaling mechanisms of developing and maturing granule cells. However, little attention has been paid to the involvement of this alteration of membrane potential in controlling granule cell development and maturation.

In primary cultures of postnatal granule cells, depolarization with high $\mathrm{KCl}$ (25 mM) enhances cell survival, differentiation, and NMDA receptor responsiveness (Gallo et al., 1987). Depolarization of cultured granule cells has thus been proposed to mimic the activity-dependent maturation of granule cells by mossy fiber input (Gallo et al., 1987) and is often used as a model system to explore regulatory mechanisms of granule cell maturation (Gu et al., 2007; Xie et al., 2007; León et al., 2008; Mundy et al., 2008). However, the use of chronic high $\mathrm{KCl}$ has been questioned. For example, these cells appear to be immature in terms of gene expression pattern, electrophysiological properties, and intracellular signaling mechanisms (Mellor et al., 1998; Suzuki et al., 2005). Furthermore, microarray analysis of granule cells cultured under the high and low $\mathrm{KCl}$ conditions has indicated that, reflecting changes in the membrane potential, the activation and inactivation of $\mathrm{CaN}$ induce the expression of many genes characteristic of immature EGL and mature IGL granule cells, respectively (Sato et al., 2005). Two important questions, however, still remain to be clarified by studying primary cultures of dissociated granule cells: (1) Are the development and maturation of granule cells regulated by altered membrane potential and its downstream $\mathrm{CaN}$ signaling during the functional network formation 
of the postnatal cerebellum? (2) At what stage does this regulation serve as a key mechanism in controlling postnatal granule cells? To address these questions, this present investigation combined the use of organotypic cerebellar cultures and green fluorescent protein (GFP)-expressing granule cells obtained by DNA transfection. The organotypic cultures of granule cells under a physiological $\mathrm{KCl}$ concentration $(5 \mathrm{~mm}$ ) reproduced the temporally regulated developmental and maturation processes of postnatal granule cells. Depolarization of these organotypic cultures with high $\mathrm{KCl}(25 \mathrm{~mm})$ similarly allowed granule cells to develop up to the stage of formation of immature dendrites but blocked the formation of mature synapses. Importantly, this blockade of mature synaptic organization was reversed by inactivation of $\mathrm{CaN}$ with tacrolimus (FK506), a specific inhibitor of it. This investigation has thus demonstrated that $\mathrm{CaN}$ regulation plays a pivotal role in functional synaptic organization during the maturation processes of granule cells.

\section{Materials and Methods}

Organotypic slice cultures of cerebellum. All procedures of animal handling were performed according to the guideline of Osaka Bioscience Institute. Organotypic slice cultures were prepared from Institute of Cancer Research (ICR) mice by using the interface membrane culture method (Stoppini et al., 1991; Tanaka et al., 1994). Mice of postnatal day 6 were anesthetized with diethyl ether, and their cerebella were removed and cut parasagitally into $400-\mu \mathrm{m}$-thick slices by using a McIlwain tissue chopper. The slices were then transferred onto 24-mm-diameter collagencoated porous $(3 \mu \mathrm{m})$ polytetrafluoroethylene membranes (Corning Life Sciences) that had been placed in a six-well tissue culture plate (Corning Life Sciences) and maintained at the interface between the air and culture medium. The culture medium consisted of $15 \%$ horse serum (Invitrogen), 25\% Earle's balanced salt solution, 60\% Eagle's basal medium (Sigma-Aldrich), $5.6 \mathrm{~g} / \mathrm{L}$ glucose, $3 \mathrm{~mm}$ L-glutamine, $5 \mu \mathrm{g} / \mathrm{ml}$ human transferrin (Sigma-Aldrich), $5 \mu \mathrm{g} / \mathrm{ml}$ bovine insulin (Sigma-Aldrich), 30 nM sodium selenite (Sigma-Aldrich), $20 \mathrm{~nm}$ progesterone (SigmaAldrich), $1 \mathrm{~mm}$ sodium pyruvate, $3 \mu \mathrm{m}$ glycine, $1.32 \mathrm{~g} / \mathrm{L}$ sodium bicarbonate, $100 \mathrm{U} / \mathrm{ml}$ penicillin, and $100 \mu \mathrm{g} / \mathrm{ml}$ streptomycin (Invitrogen). The cultures were incubated at $33^{\circ} \mathrm{C}$ in $5 \% \mathrm{CO}_{2} / 95 \%$ air. One-half of the volume of the medium was replaced with fresh medium every 3 or $4 \mathrm{~d}$.

The cells in the slices were transfected with pCAGGS-EGFP or pUB6EGFP at day in vitro (DIV) 0 by using Lipofectamine LTX (Invitrogen) according to the manufacturer's instructions. Plasmids pCAGGS-EGFP and pUB6-EGFP were generated by inserting the enhanced green fluorescent protein (EGFP) gene into pCAGGS (a gift from Jun-ichi Miyazaki, Osaka University, Osaka, Japan) and pUB6/V5-HIS (Invitrogen), respectively. Before transfection, the slices attached to the membrane were transferred onto Opti-MEM (Invitrogen) in tissue culture wells. Transfection mixtures in Opti-MEM were added directly onto the slices. At 1-4 h after transfection, the reagent mixture was removed and the membranes were reinserted into the six-well tissue culture plates containing the above-described culture medium.

Patch-clamp recording of cultured cerebellar slices. Patch-clamp recordings were performed as described previously (Kadotani et al., 1996; Okazawa et al., 2002). A small cut membrane with cultured slices attached to it was put into a chamber on the stage of an Olympus BX51 epifluorescence microscopy. The slices were perfused at $1-2 \mathrm{ml} / \mathrm{min}$ with Krebs' solution containing the following (in $\mathrm{mM}$ ): $140 \mathrm{NaCl}, 5 \mathrm{KCl}, 2 \mathrm{CaCl}_{2}, 2$ $\mathrm{MgCl}_{2}, 10$ HEPES, and 10 glucose; in some experiments, when cells were cultured at $25 \mathrm{~mm} \mathrm{KCl}, 5 \mathrm{~mm} \mathrm{KCl}$ was replaced with $25 \mathrm{~mm} \mathrm{KCl}$. The $\mathrm{pH}$ of the solution was adjusted to 7.35 with $\mathrm{NaOH}$. Recordings were performed with an EPC-9 or an EPC-10 USB amplifier and PATCHMASTER software (HEKA Electronik). The data were sampled every $20 \mu \mathrm{s}$ and filtered at $2.9 \mathrm{kHz}$ using a digital Bessel filter. Data were also analyzed with a PowerLab system (ADInstruments Pty). The internal solution in a patch pipette contained the following (in $\mathrm{mm}$ ): $130 \mathrm{~K}$-gluconate, $2 \mathrm{NaCl}$, $1 \mathrm{CaCl}_{2}, 5 \mathrm{EGTA}, 4 \mathrm{MgSO}_{4}, 2 \mathrm{Na}_{2}$-ATP, and 10 HEPES, the $\mathrm{pH}$ of which was adjusted to 7.3 with $\mathrm{KOH}$. Recordings were obtained from EGFP- expressing granule cells identified under epifluorescence at room temperature $\left(22-25^{\circ} \mathrm{C}\right)$. The perfusion was stopped before formation of the seal. After a whole-cell configuration had been established, cell membrane capacitance was electronically compensated. The resting membrane potential was measured within a minute after formation of the whole-cell mode. When recording spontaneous IPSCs, the recording chamber was perfused with Krebs' solution containing $10 \mu \mathrm{M}$ CNQX (6-cyano-7-nitroquinoxaline-2,3-dione) and $50 \mu \mathrm{M}$ D-AP-5 (D-2amino-5-phosphonopentanoic acid) and clamped at $-20 \mathrm{mV}$. A measured liquid junction potential of $11 \mathrm{mV}$ was corrected.

Immunohistochemistry and imaging. Cultured slices were fixed with $4 \%$ paraformaldehyde and $4 \%$ sucrose in PBS at room temperature for 5 min (for PSD-95) or overnight at $4^{\circ} \mathrm{C}$ (for other proteins). After having been blocked with $2 \%$ normal goat serum and $0.25 \%$ Triton X-100 in PBS for $2-4 \mathrm{~h}$ at room temperature or overnight at $4^{\circ} \mathrm{C}$, the slices were reacted with the primary antibody for $48-96 \mathrm{~h}$ at $4^{\circ} \mathrm{C}$ followed by reaction with the Alexa Fluor 594-conjugated secondary antibody (Invitrogen). Confocal images were acquired with a Zeiss LSM-510 META confocal inverted microscope. Antibodies were purchased from the following sources: Homer 2 polyclonal antibody from COSMO BIO; $\mathrm{GABA}_{\mathrm{A}} \alpha 6$ receptor $\left(\mathrm{GABA}_{\mathrm{A}} \alpha 6\right)$ polyclonal antibody, synaptophysin monoclonal antibody, and glutamic acid dehydrogenase (GAD)65/67 polyclonal antibody from Millipore Bioscience Research Reagents; PSD-95 monoclonal antibody from Affinity Bioreagents; and calbindin D-28k monoclonal antibody from Sigma-Aldrich. FK506 was obtained from Astellas Pharma. Percentages of immunoreactive areas and punctate densities of marker proteins were calculated by use of MetaMorph software, version 7.5.2 (Molecular Devices)

Statistical analysis. Statistical analysis was conducted by using unpaired Student's $t$ test or one-way ANOVA, followed by Tukey's honestly significant differences. Statistical significance and response curves were obtained with GraphPad Prism software.

\section{Results \\ Developmental changes in morphology of granule cells in organotypic slice cultures}

Organotypic cerebellar cultures were prepared from 6-d-old ICR mice. Slices were mounted on a collagen-coated porous polytetrafluoroethylene membrane, which was floated at the interface between the air and culture medium in a six-well plate. The cultures were incubated in the medium containing 15\% horse serum with $5 \mathrm{~mm} \mathrm{KCl}$ and maintained at $33^{\circ} \mathrm{C}$ in $5 \% \mathrm{CO}_{2} / 95 \%$ air. The developing and maturing granule cells in vivo at the postnatal period have been well characterized by changes in their morphology and location in the cerebellar architecture and classified into several stages (Fig. 1A) (Larramendi, 1969; Ramón y Cajal, 2000). In the germinal and horizontal stage (stage I), the granule cells proliferate and differentiate in the EGL and extend longitudinally their thin processes parallel to the axis of the folia. In the migratory stage (stage II), the granule cells and their dendritic processes vertically migrate downward into the IGL by passing through the molecular layer (ML). The descending granule cells leave horizontal processes in the EGL and thus show a T-shaped bifurcation. In the multipolar stage (stage III), the granule cells reach the IGL and generate a number of dendritic processes. In the mature stage (stage IV), the granule cells become fully mature, at which time the number of dendrites decreases and a claw-like structure is formed at the tip of the remaining dendrites.

Nissl staining showed the well preserved overall and typically layered structure of the cerebellar cortex in the organotypic cultures (Fig. $1 B$ ). Anti-calbindin D immunofluorescence disclosed Purkinje cells organized in a single layer and showing a well polarized morphology (Fig. 1C). To examine whether granule cells in the organotypic cultures could recapitulate the development and maturation of granule cells in vivo, we introduced the EGFP expression vector into organotypic slices (Fig. 1C) and micro- 

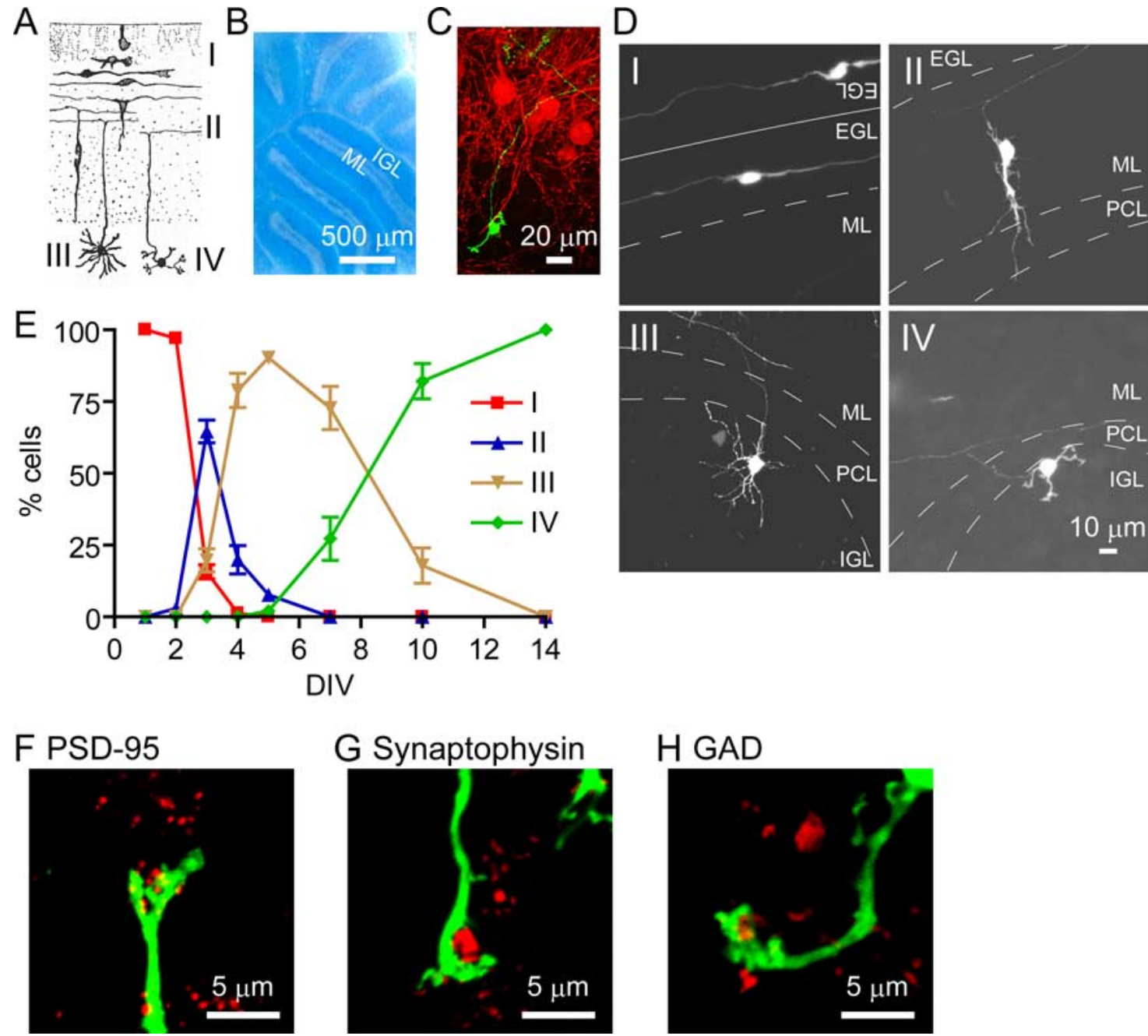

Figure 1. Ontogenic changes in granule cells in organotypic cultures. A, Schematic drawing of morphological and locational changes in granule cells at the postnatal period in vivo [cited and modified from Ramón y Cajal (2000)]. Granule cells are classified into four stages according to their morphology and location: stage I, a germinal and horizontal stage; stage II, a descending stage; stage III, a multipolar stage; stage IV, a mature stage. B, A well preserved cerebellar architecture at DIV 10 is shown by Niss staining of a representative organotypic culture. C, An EGFP-expressing granule cell and Purkinje cells in a representative organotypic culture at DIV 10 are shown by EGFP fluorescence (green) and calbindin D immunostaining (red), respectively. D, Morphological changes of representative granule cells at four stages in organotypic slice cultures. Confocal images were obtained from EGFP-expressing granule cells, indicating stage I at DIV 2, stage II at DIV 3, stage III at DIV 4, and stage IV at DIV 10. In D-I, two adjacent EGLs were separated as marked by a solid line. PCL, Purkinje cell layer. $\boldsymbol{E}$, Time-dependent changes in a cell population of four developmental stages of granule cells in organotypic slice cultures. Three cerebellar slices were placed on a culture membrane and subjected to organotypic culture in a six-well plate. EGFP-positive granule cells in six slices were classified at each time point, and the numbers of different stages of granule cells in these slices were counted and averaged. Experiments were performed three times, and data of a representative experiment are presented. The symbols and bars represent the mean \pm SEM, respectively. $\boldsymbol{F}-\boldsymbol{H}$, Synaptic maturation of granule cells at stage IV. Expression of postsynaptic PSD-95 and presynaptic synaptophysin and GAD was visualized by immunostaining with the respective antibodies (red) and observed over or adjacent to the claw-like structure of a granule cell dendrite (green).

scopically characterized the fluorescence-positive EGFPexpressing granule cells at DIV $1,2,3,4,5,7,10$, and 14 . We could identify and classify EGFP-expressing granule cells according to changes in their morphology in the layered cerebellar structure (Fig. $1 D, E$ ). Stage I cells were exclusively observed at DIV 1 and 2 and disappeared by DIV 4. Stage II cells transiently appeared from DIV 2 to DIV 5. Stage II cells then shifted to stage III cells, which appeared from DIV 3 up to DIV 10. However, a small portion of granule cells failed to migrate inwardly and extended multiple immature dendrites $(11.1 \pm 2.8 \% ; n=18)$. This cell population was easily identified and was excluded from the ontogenic analysis of developing granule cells. Stage IV cells started to appear at DIV 7 and became the predominant population of granule cells at DIV 10. The time-dependent shift of the developmental stages of granule cells thus matched that of granule cells observed in vivo.
To verify the mature synaptic organization of stage IV granule cells, we immunostained organotypic slices at DIV 10 with antibodies against PSD-95, a postsynaptic marker protein (Fig. $1 F$ ) and synaptophysin, a presynaptic marker protein (Fig. $1 G$ ). The synaptophysin immunoreactivity was surrounded by the clawlike structure of a mature granule cell, whereas the PSD-95 immunoreactivity was highly located at the dendritic tip of an EGFP-positive granule cell. In the cerebellum, the GABAergic Golgi cell projects its axonal terminal onto granule cell dendrites (Eccles et al., 1967). The axonal innervation of the GABAergic cells was also disclosed at a claw-like structure by immunostaining for GAD, a GABAergic neuronal cell marker (Fig. $1 H$ ). These results thus indicate that EGFP-expressing granule cells in organotypic cultures recapitulate morphological changes of developing and maturing granule cells in a temporally regulated manner. 
A
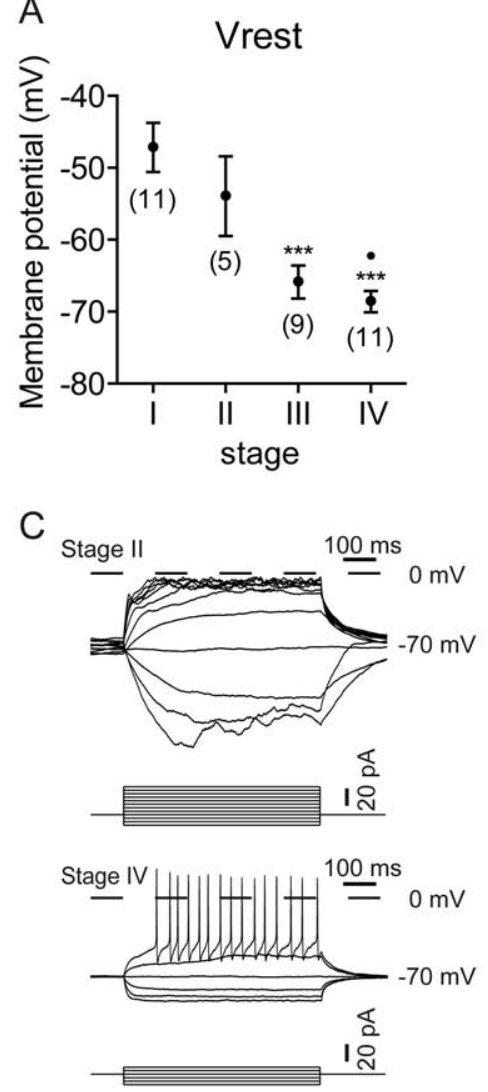

B

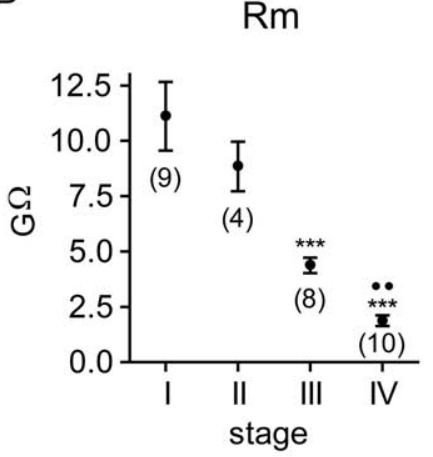

D

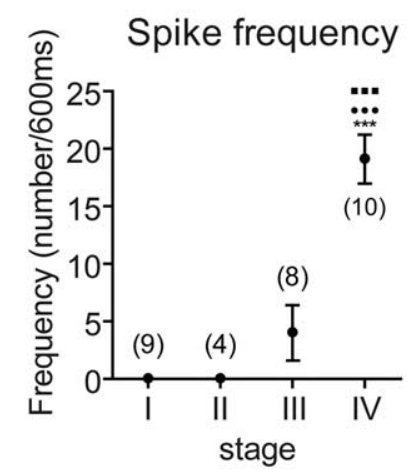

\section{E inward current}

\section{$\mathrm{F}$}

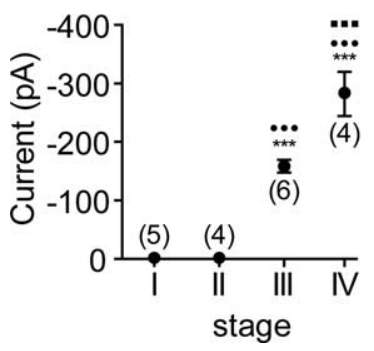

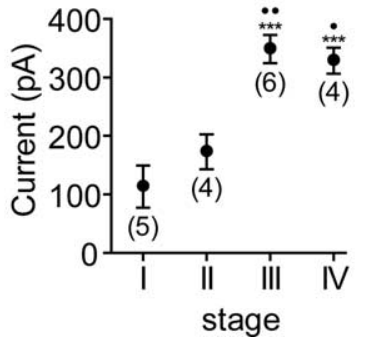

\section{G

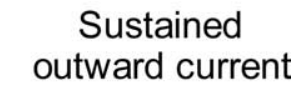 \\ Transient outward current}

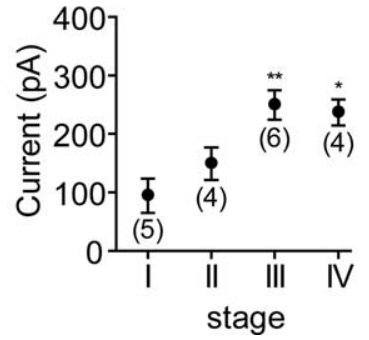

Figure 2. Changes in electrophysiological properties of developing granule cells in organotypic slice cultures. $A, B$, Resting membrane potentials $\left(V_{\text {rest }}\right)$ and membrane resistances $\left(R_{\mathrm{m}}\right)$ of granule cells at four stages are indicated. The resting membrane potential and membrane resistance progressively decreased from stage I to stage IV. C, D, Action potentials evoked by injecting indicated currents for $600 \mathrm{~ms}$ were measured from granule cells at the four stages at the holding potential of $-70 \mathrm{mV}$. Representative voltage traces of stages II and IV $(\boldsymbol{C})$ and frequencies of action potentials at the four stages $(\boldsymbol{D})$ are indicated. $\boldsymbol{E}-\boldsymbol{G}$, Average peak amplitudes of inward currents $(\boldsymbol{E})$ and those of outward currents at the peak (transient; $\boldsymbol{F}$ ) and at the plateau phase (sustained; $\boldsymbol{G}$ ) were determined for granule cells at the four stages by changing the membrane potential from the holding potential of $-70 \mathrm{mV}$ to the test potential of $-30 \mathrm{mV}(\boldsymbol{E})$ or $10 \mathrm{mV}(\boldsymbol{F}, \boldsymbol{G})$. Statistical analysis was done by one-way ANOVA, followed by Tukey's multiple-comparison tests. The symbols and bars represent the mean \pm SEM, respectively. The numbers in parentheses are numbers of cells examined. In all analyses, ${ }^{*} p<0.05,{ }^{* *} p<0.01,{ }^{* * *} p<0.001$ compared with stage I; ${ }^{*} p<$ $0.05,{ }^{\bullet \bullet} p<0.01, \cdots p<0.001$ compared with stage II; ${ }^{\cdots} p<0.001$ compared with stage III.

\section{Developmental changes in electrophysiological properties of cultured granule cells}

Previous studies indicated marked changes in the electrophysiological properties of developing granule cells in vivo (D'Angelo et al., 1994; Rossi et al., 1998; Cathala et al., 2003). To examine whether these changes also occur in organotypically cultured granule cells, we performed whole-cell patch-clamp recordings of granule cells at different stages in culture.
Resting membrane potential

It has been reported that immature granule cells in the EGL display a high level of resting membrane potential (approximately $-23 \mathrm{mV}$ ) with high input resistance, which gradually becomes more negative (approximately $-58 \mathrm{mV}$ ) with low input resistance (Rossi et al., 1998). So we determined the resting membrane potential of organotypically cultured granule cells immediately after establishing a whole-cell recording configuration of the cells (Fig. 2A). The resting membrane potentials of granule cells at stages I to IV were $-47.2 \pm 3.4 \mathrm{mV}(n=11),-53.9 \pm$ $5.5 \mathrm{mV}(n=5),-65.9 \pm 2.3 \mathrm{mV}(n=9)$, and $-68.6 \pm 1.5 \mathrm{mV}(n=11)$, respectively (Fig. 2A). When input membrane resistances were calculated from voltage responses to a constant current injection at the holding potential of $-70 \mathrm{mV}$, they were gradually lowered from stage I to stage IV (Fig. $2 B$ ).

\section{Action potential and}

voltage-activated currents

When depolarizing currents were applied under a whole-cell current-clamp configuration, granule cells at stages I and II never generated an action potential at the holding potential of $-70 \mathrm{mV}$ (Fig. 2C,D). In contrast, granule cells at stages III and IV evoked action potential under the same conditions, and the frequency of action potential significantly increased from stage III to stage IV (Fig. $2 C, D$ ). The stagedependent appearance of action potential in cultured cells is in a good agreement with that reported in granule cells in acute slice preparations (Rossi et al., 1998).

In recordings of acute slices, immature granule cells in the EGL inconstantly express small inward $\mathrm{Ca}^{2+}$ currents but no fast inward $\mathrm{Na}^{+}$currents, whereas mature granule cells in the IGL markedly express both $\mathrm{Na}^{+}$and $\mathrm{Ca}^{2+}$ currents (D'Angelo et al., 1994). When voltage-dependent currents in cultured granule cells at different stages were recorded from the holding potential of $-70 \mathrm{mV}$ to different test potentials, voltage-activated inward currents were evoked in stage III and IV cells but not in stage I and II ones (Fig. 2E). As reported to occur in acute slices (D'Angelo et al., 1994), both transiently and sustainedly activated outward currents were recorded from cultured granule cells of all stages, but both outward currents increased as the developmental stage of the cultured cells advanced (Fig. $2 F, G$ ). Thus, granule cells in organotypic cultures showed distinct stage-dependent electrophysiological properties, and these changes in the electrophysiological properties were all consistent with those reported for developing and maturing granule cells in vivo. 


\section{Developmental expression of marker proteins}

To further substantiate the development and maturation of granule cells in the organotypic cultures, we immunostained cultured slices with antibodies against several marker proteins characteristic of different stages of granule cells (Fig. 3A): TAG-1 mainly for postproliferative EGL cells and partly for the migratory cells (Stottmann and Rivas, 1998); Homer 2 for the migratory and immature IGL cells and slightly expressed in the mature cells (Shiraishi et al., 2004); and $\mathrm{GABA}_{\mathrm{A}} \alpha 6$ for the mature cells (Mellor et al., 1998). The distribution of immunoreactivity was quantified by expressing it as either percentages of immunoreactive areas or the number of punctate immunoreactivity (Fig. 3B). The TAG-1 immunoreactivity was mainly detected in cells at stage I, whereas the Homer 2 immunoreactivity was observed from stage II to stage IV, but its distribution in dendrites was predominant at stage III. The $\mathrm{GABA}_{A} \alpha 6$ immunoreactivity has been reported to be prominently distributed at the dendritic terminals of mature granule cells (Nusser et al., 1996). This immunoreactivity was significantly observed at the dendrites of both GFP-positive and GFP-negative granule cells at DIV 10 (Fig. $3 A$ ) and increased from stage III to stage IV at the soma and dendrites of GFPpositive granule cells (Fig. 3B). The ontogenic expression of the marker proteins was thus consistent with that observed in vivo, and the synaptic maturation proceeded from stage III to stage IV in the organotypically cultured granule cells.

\section{Blockade of granule cell maturation by} membrane depolarization via

\section{CaN signaling}

The above characterization indicated that granule cells in organotypic cultures under the physiological $\mathrm{KCl}$ concentration reproduced the temporally regulated developmental and maturation processes of postnatal granule cells. So next we addressed how and at what stages membrane depolarization and its downstream $\mathrm{CaN}$ signaling control developmental and maturation processes of granule cells by culturing organotypic slices at high $\mathrm{KCl}(25$ $\mathrm{mm}$ ) from DIV 3 to DIV 10. This shifting of the $\mathrm{KCl}$ concentration had no effect on the time-dependent changes in the morphology of granule cells up to stage III (Fig. 4). However, the stage III cells, which possess multiple dendritic processes, never proceeded to stage IV cells and failed to exhibit the characteristic mature claw-like structure of the dendrite (Fig. $4 A, B, E$ ).
A
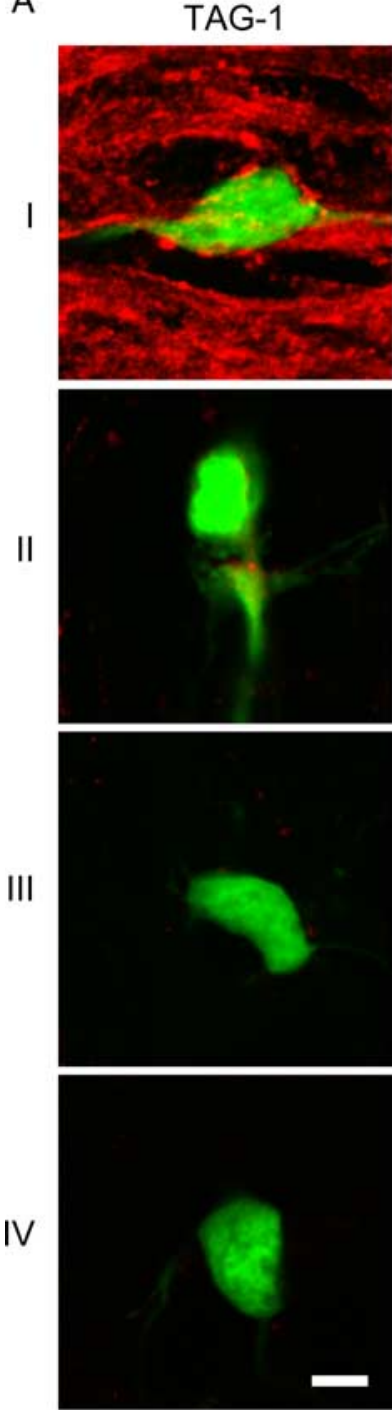

B

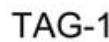

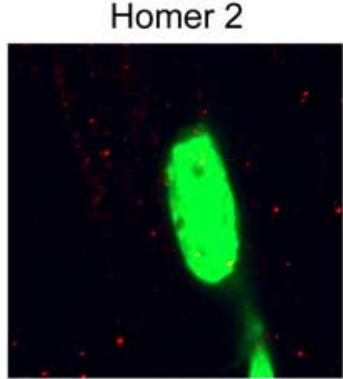
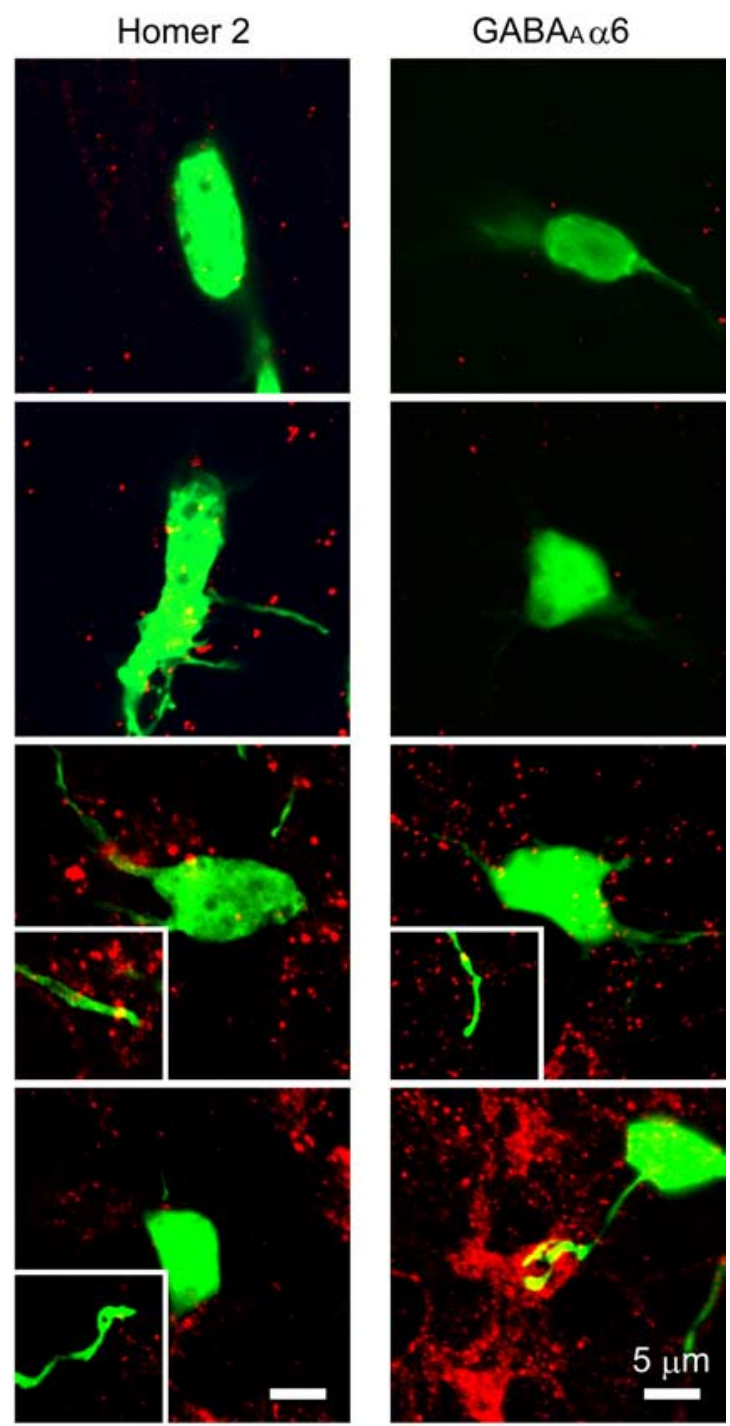

Homer 2

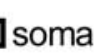

GABAA 6 dendrite
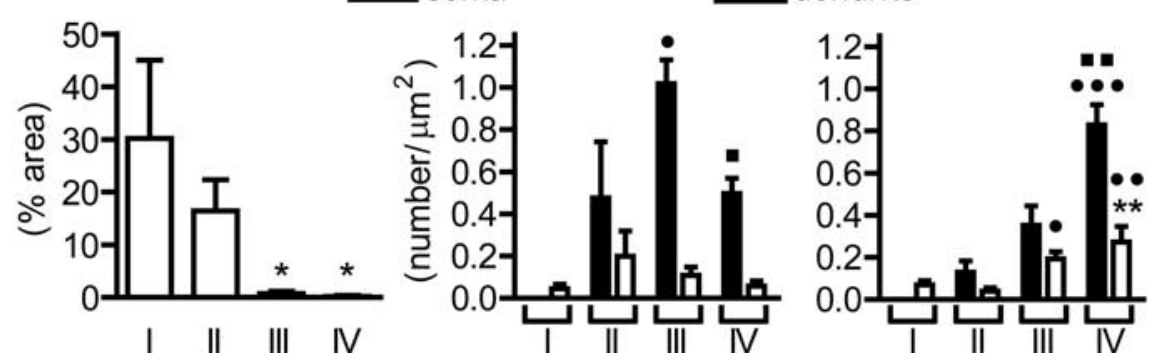

Figure 3. Ontogenic expression of marker proteins in organotypically cultured granule cells. $A$, Confocal images of expression of TAG-1, Homer 2, and GABA $\alpha 6$ in EGFP-expressing cells at four stages as analyzed by EGFP fluorescence (green) and immunostaining with the respective antibodies (red). The insets indicate immunostained Homer 2 and $\mathrm{GABA}_{\mathrm{A}} \alpha 6$ at dendrites of EGFPexpressing granule cells. $\boldsymbol{B}$, Quantification of immunostained marker proteins in granule cells. The distribution of immunoreactivity is expressed as either percentages of immunoreactive area (TAG-1) or numbers of immunofluorescent puncta (Homer 2 and $\mathrm{GABA}_{\mathrm{A}} \alpha 6$ ). The black and white columns indicate numbers of fluorescent puncta at the dendrites and somas of the EGFPexpressing granule cells, respectively. The columns and bars represent the mean \pm SEM, respectively. Numbers analyzed for dendritic and somatic distributions were 4-14 and 3-9, respectively. The distribution of immunoreactivity in somas was statistically analyzed for all four stages, and that in dendrites was done for stages II, III, and IV. Statistical analysis was performed by one-way ANOVA, followed by Tukey's multiple-comparison tests. In all analyses, ${ }^{*} p<0.05,{ }^{* *} p<0.01$ compared with stage I;

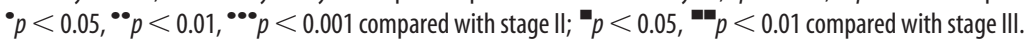



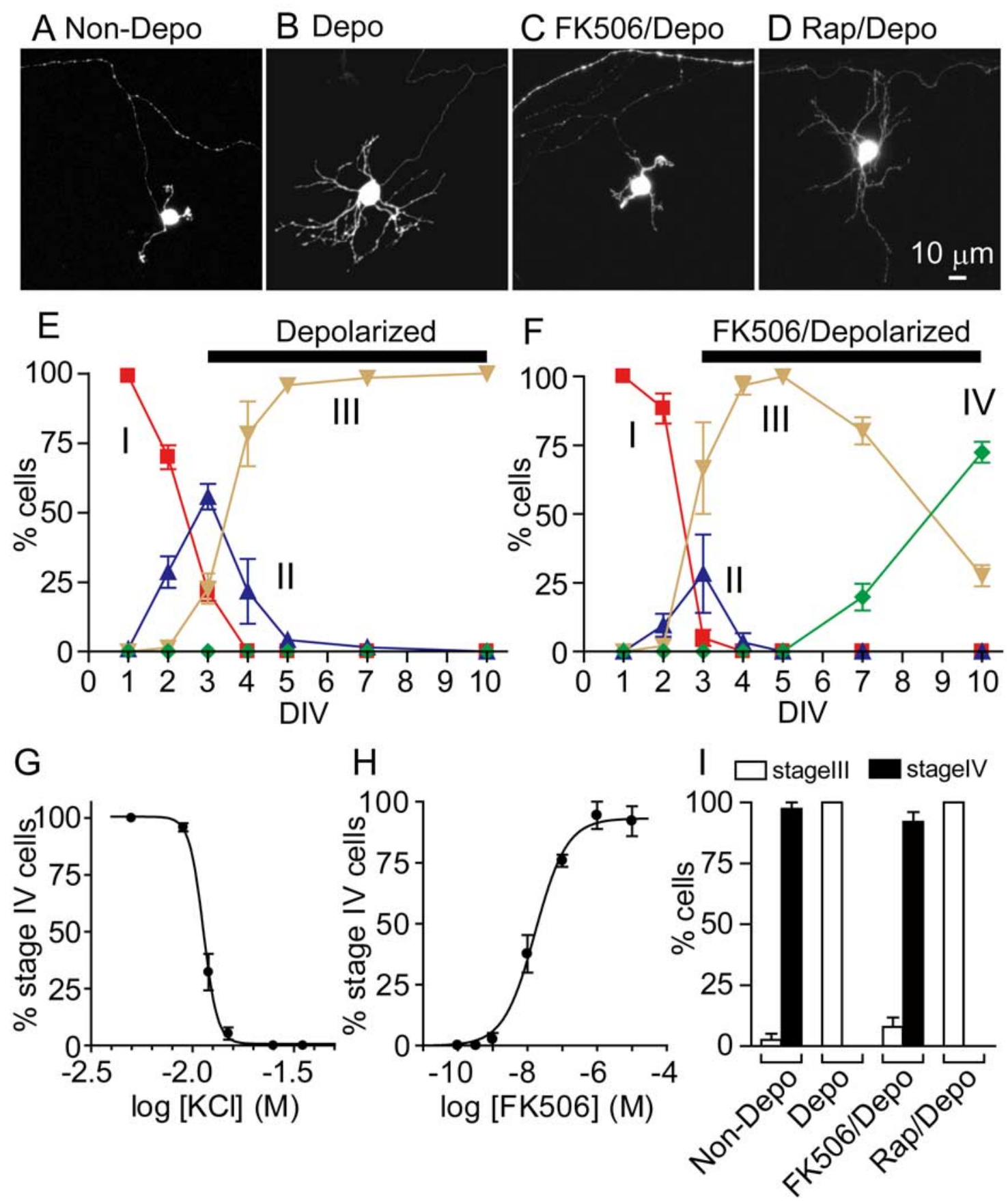

Figure 4. Blockade of the maturation of granule cells by membrane depolarization with high $\mathrm{KCl}$ via the CaN signaling. $A-D$, Organotypic slices were cultured under different conditions from DIV 3 to DIV 10, and images of EGFP-expressing granule cells were obtained by confocal microscopy at DIV 10: Non-Depo, 5 mм KCI (A); Depo, 25 mm KCI (B); FK506/Depo, 25 mm KCI with $10 \mu$ m FK506 (C); Rap/Depo, $25 \mathrm{~mm} \mathrm{KCl}$ with $10 \mu$ m rapamycin (D). $\boldsymbol{E}, \boldsymbol{F}$, Time courses of granule cell development and maturation under the culture conditions with $25 \mathrm{~mm} K C \mathrm{C}$ in the presence $(\boldsymbol{F})$ and absence $(\boldsymbol{E})$ of $10 \mu \mathrm{M}$ FK506. Percentages of different stages of granule cells were determined as described in Figure 1 E. G, Percentages of stage IV granule cells at DIV 10 when cultures were maintained in media containing $5,9,12,15,25$, or $35 \mathrm{~mm} \mathrm{KCI}$. $\boldsymbol{H}$, Percentages of stage IV granule cells at DIV 10 when cultures were maintained in media containing $25 \mathrm{~mm}$ KCI with various concentrations of FK506. $\boldsymbol{I}$, Percentages of stage III and stage IV granule cells at DIV 10 when the cells were cultured at 5, 25, or $25 \mathrm{~mm} \mathrm{KCl}$ in the presence of either $10 \mu \mathrm{m}$ FK506 or $10 \mu \mathrm{m}$ rapamycin. In $\boldsymbol{E}-\boldsymbol{I}$, experiments of organotypic cultures were performed three times, and data shown are from a representative experiment. The symbols/columns and bars represent the mean \pm SEM, respectively.

The blockade of granule cell maturation was dependent on the concentrations of external $\mathrm{KCl}$. When a logistic function was fitted to the dependency on $\mathrm{KCl}$ concentrations, the $\mathrm{IC}_{50}$ for the $\mathrm{KCl}$-induced blockade of granule cell maturation was $12.2 \pm 0.43$ $\mathrm{mm}(n=3)$ (Fig. $4 G)$. Noteworthy is that this $\mathrm{IC}_{50}$ value is in good agreement with the $\mathrm{IC}_{50}$ of $15.3 \mathrm{~mm}$ for the $\mathrm{KCl}$-induced blockade of expression of the maturation marker $\mathrm{GABA}_{\mathrm{A}} \alpha 6$ in primary cultures of dissociated granule cells (Mellor et al., 1998).
We next examined the involvement of the $\mathrm{CaN}$ cascade in the maturation process of granule cells by administering the CaN inhibitor FK506 to high KCl-treated organotypic cultures from DIV 3 to DIV 10 (Fig. 4F,I). Remarkably, FK506 reduced the number of dendrites and generated a claw-like structure, thus restoring granule cell maturation (Fig. $4 C, F, I$ ). The $\mathrm{EC}_{50}$ for the restoring effect of FK506 was determined to be $17.4 \pm 3.2 \mathrm{~nm}$ (Fig. $4 \mathrm{H}$ ), which is close to the $\mathrm{IC}_{50}$ of $40 \mathrm{~nm}$ for the inhibition of 
FK506 on the CaN phosphatase activity (Satoh et al., 2008). In contrast, neither rapamycin $(10 \mu \mathrm{M})$, which does not target CaN (Fig. 4D,I) (Liu et al., 1991), nor the CaMK II inhibitor KN93 (2-[N-(2hydroxyethyl)]-N-(4-methoxybenzenesulfonyl)amino- $N$-(4-chloro-cinnamyl)$N$-methylbenzylamine) (data not shown) restored granule cell maturation in cultures at high $\mathrm{KCl}$.

The blockade of granule cell maturation by membrane depolarization and its recovery by FK506 treatment were further confirmed by immunohistochemical quantification of marker proteins as well as immunohistochemical localization of the presynaptic synaptophysin (Fig. 5). Consistent with the lack of a claw-like structure of the depolarized granule cell, the synaptophysin immunoreactivity was not located adjacent to the GFP-positive dendrites (Fig. 5G). The appearance of a claw-like structure and its localization adjacent to the synaptophysin immunoreactivity after FK506 treatment were clearly observed by immunostaining for the presynaptic synaptophysin (Fig. 5G). Immunohistochemical quantification further indicated no ontogenic induction of $\mathrm{GABA}_{\mathrm{A}} \alpha 6$ or PSD-95 in granule cells at DIV 10 under the depolarizing condition (Fig. 5A,B,E,F). Remarkably, similar to that in low $\mathrm{KCl}$-treated cultures, the expression of $\mathrm{GABA}_{\mathrm{A}} \alpha 6$ and PSD-95 was markedly induced, and these proteins were abundantly located at mature dendrites at DIV 10 by the addition of FK506 to cultures of depolarized granule cells (Fig. $5 A, B, E, F$ ). In contrast, Homer 2 immunoreactivity was present on dendrites of depolarized granule cells at stage III but was never increased by treatment with FK506 (Fig. 5C,D). This immunohistochemical analysis thus further supports the time-dependent blockade of granule cell maturation by membrane depolarization and its recovery by FK506 treatment.

We then examined whether FK506 would influence the electrophysiological properties of granule cells by recording granule cells cultured at DIV 10-14 at high $\mathrm{KCl}$ in the presence and absence of FK506. The membrane potential of granule cells cultured and recorded at $25 \mathrm{mM} \mathrm{KCl}$ was more positive $(-38.7 \pm$ $3.7 \mathrm{mV} ; n=3$ ) (Fig. 6A) than that of the cells cultured and recorded at $5 \mathrm{~mm} \mathrm{KCl} \mathrm{(Fig.} 2 A$ ), but this depolarized state was not influenced by the addition of FK506 $(-42.6 \pm 1.5 \mathrm{mV} ; n=5)$ (Fig. 6A). In both FK506-treated and untreated cells, current injection into granule cells recorded at their depolarized state with $25 \mathrm{~mm} \mathrm{KCl}$ produced no action potentials in any of the cells tested $(n=3-4)$ (Fig. 6B). This was in marked contrast to the case when cells were cultured and recorded at $5 \mathrm{~mm} \mathrm{KCl} \mathrm{(Fig.} \mathrm{2C).}$ When granule cells were chronically cultured at $25 \mathrm{mM} \mathrm{KCl}$ with
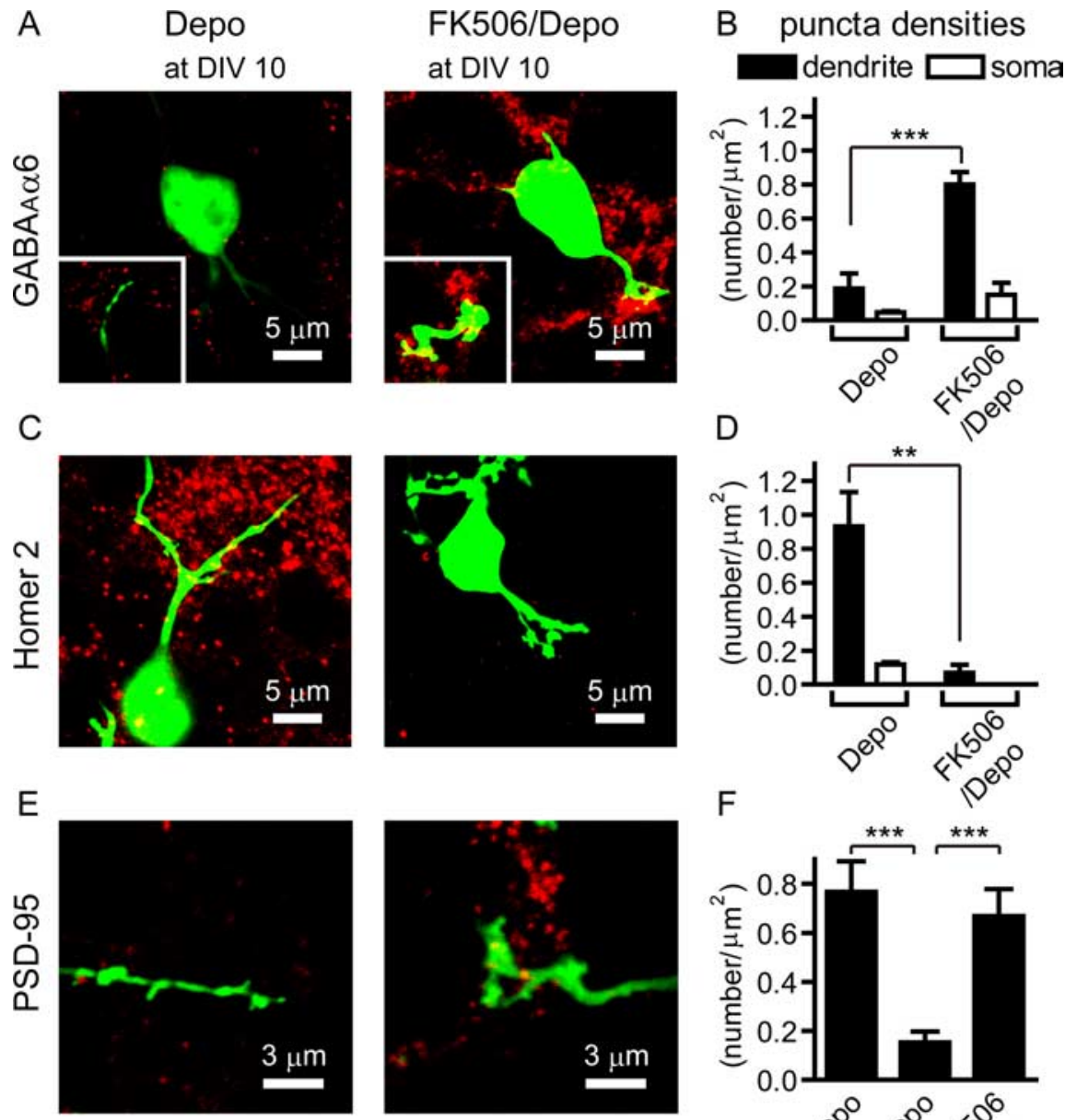

F
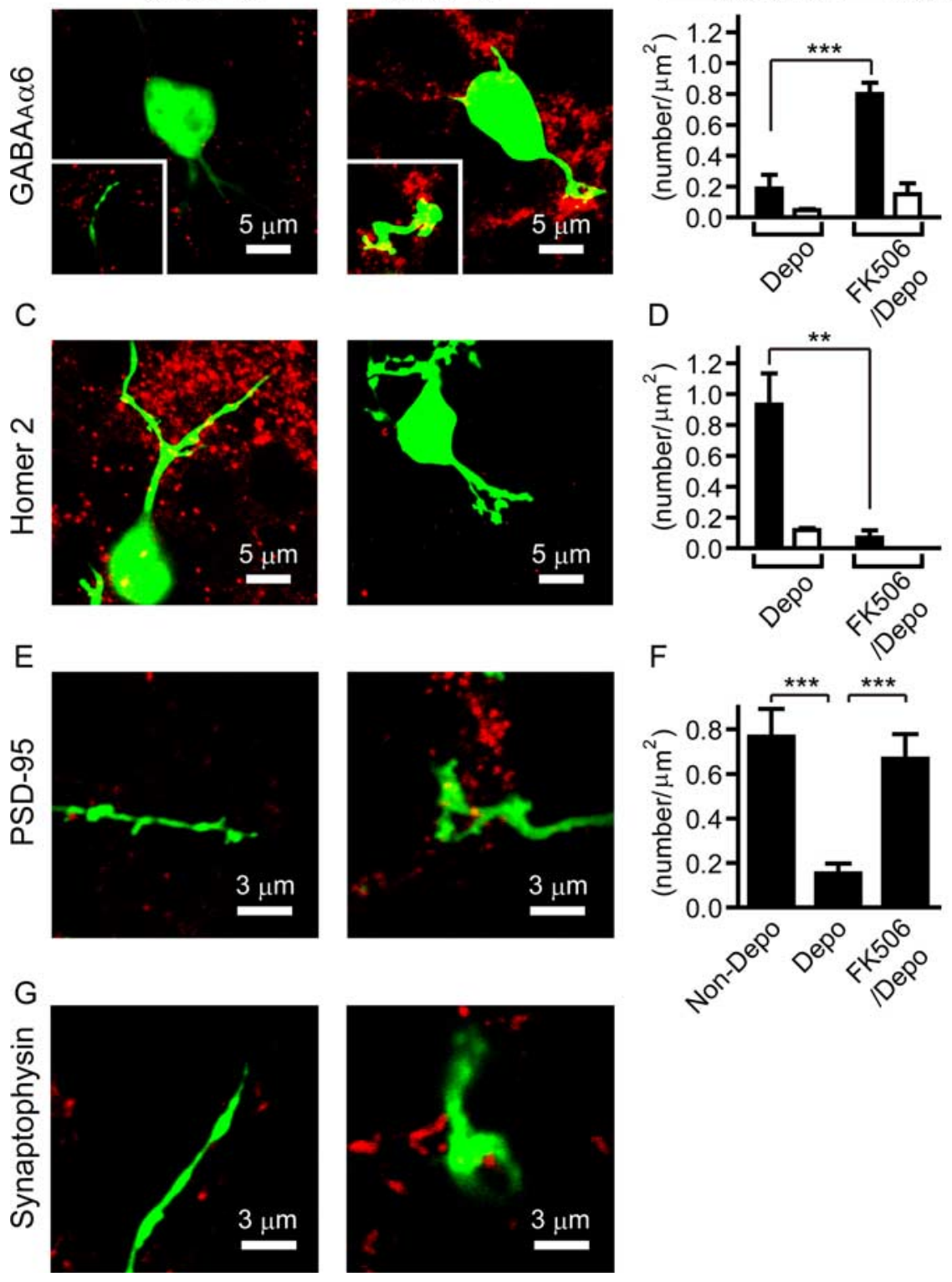

Figure 5. Expression of marker proteins in granule cells cultured under the depolarized condition in the presence and absence of FK506. A, C, E, G, Confocal images of expression of GABA $A_{A} \alpha 6(\boldsymbol{A})$, Homer $2(\boldsymbol{C})$, PSD-95 (E), and synaptophysin (G) as analyzed by EGFP fluorescence (green) and immunostaining with the respective antibodies (red) at DIV 10. Immunostained $G_{A B A_{A}} \alpha 6$ at dendrites is indicated in the insets. $\boldsymbol{B}, \boldsymbol{D}$, Quantification of immunostained $\mathrm{GABA}_{A} \alpha 6(\boldsymbol{B})$ and Homer $2(\boldsymbol{D})$ in granule cells. The black and white bars indicate the number of immunostained puncta of $\mathrm{GABA}_{A} \alpha 6$ and Homer 2 at the dendrites $(n=7-10)$ and somas $(n=3-4)$, respectively, of EGFP-expressing granule cells at DIV 10.F, Quantification of immunostained PSD-95 in granule cells at DIV 10 under the indicated conditions $(n=6-10)$. Statistical analysis was done by using unpaired Student's test for $B$ and $\boldsymbol{D}$, and by one-way ANOVA, followed by Tukey's multiple-comparison tests for $\boldsymbol{F}$. The columns and bars represent the mean \pm SEM, respectively. ${ }^{* *} p<0.01 ;{ }^{* * *} p<0.001$.

or without FK506 and then recorded at $5 \mathrm{~mm} \mathrm{KCl}$, there was no difference in resting membrane potential or membrane resistance between granule cells cultured at 5 or $25 \mathrm{mM} \mathrm{KCl}$ regardless of the presence or absence of FK506 in $25 \mathrm{~mm} \mathrm{KCl}$ cultures (Fig. $6 C, D)$. Furthermore, the generation of action potentials was restored in granule cells cultured at $25 \mathrm{mM} \mathrm{KCl}$ simply by hyperpolarizing the resting membrane potential with a shift of recording conditions from 25 to $5 \mathrm{~mm} \mathrm{KCl} \mathrm{(Fig.} 6 E$ ); spike frequencies/600 ms, $16.3 \pm 2.3$ for Depo; $22.5 \pm 6.8$ for FK506/Depo $(n=3-4)$. These results explicitly demonstrate that the intracellular inacti- 
A

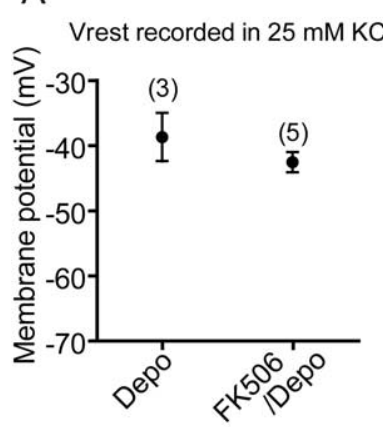

C

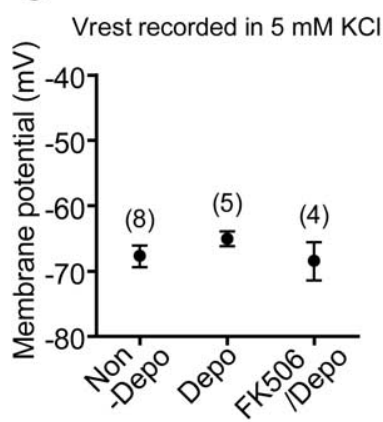

E

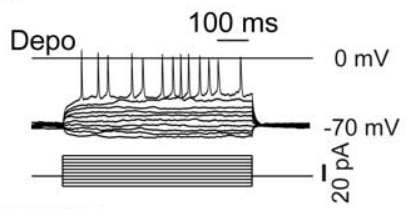

FK506/Depo

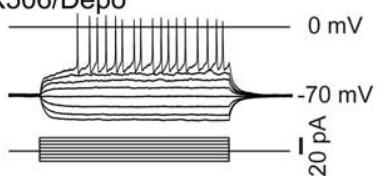

Figure 6. Effects of high $\mathrm{KCl}$ and FK506 on electrophysiological properties of organotypically cultured granule cells. $\boldsymbol{A}, \boldsymbol{B}$, Organotypic slices were cultured at $25 \mathrm{~mm} \mathrm{KCl}$ in the presence or absence of $10 \mu \mathrm{M}$ FK506. Resting membrane potentials $\left(V_{\text {rest }}\right)$ and action potentials evoked by injecting the indicated currents for 600 ms were measured from granule cells at DIV 10 -14 as described in Figure 2, except that recording was performed at $25 \mathrm{~mm} \mathrm{KCl}$. Representative voltage traces are indicated in $\boldsymbol{B}$. $\boldsymbol{C}-\boldsymbol{E}$, Organotypic slices were cultured at $5 \mathrm{~mm} \mathrm{KCl}$ or $25 \mathrm{~mm} \mathrm{KCl}$ with or without $10 \mu \mathrm{m}$ FK506. Resting membrane potential $\left(\boldsymbol{C}\right.$, membrane resistance $\left(R_{\mathrm{m}}\right)(\boldsymbol{D})$, and action potentials $(\boldsymbol{E})$ of granule cells at DIV $10-14$ were measured as described in Figure 2 by recording these cells at $5 \mathrm{~mm} \mathrm{KCl}$ within $1 \mathrm{~min}$ after formation of the whole-cell mode. The numbers in parentheses $(\boldsymbol{A}, \boldsymbol{C}, \boldsymbol{D})$ are numbers of cells examined.

vation of the CaN signaling cascade by the hyperpolarized membrane potential is essential for the terminal maturation of granule cells.

\section{Maturation of GABAergic transmission in organotypically} cultured granule cells

Because GABAergic interneurons appeared to be connected to dendrites of stage IV granule cells in organotypic cultures (Fig. $1 \mathrm{H}$ ), we examined whether inhibitory synaptic transmission is developed in the cultures, depending on the CaN signaling cascade, by recording granule cells cultured in low $\mathrm{KCl}$, high $\mathrm{KCl}$, and high $\mathrm{KCl}$ together with FK506. Stage IV cells cultured at low $\mathrm{KCl}$ (seven of nine) showed IPSCs with a mean frequency of $0.50 \pm 0.13 \mathrm{~Hz}(n=7)$ and a mean amplitude of $17.3 \pm 1.3 \mathrm{pA}$ $(n=19)$ (Fig. 7A). These currents were reversibly blocked by 20
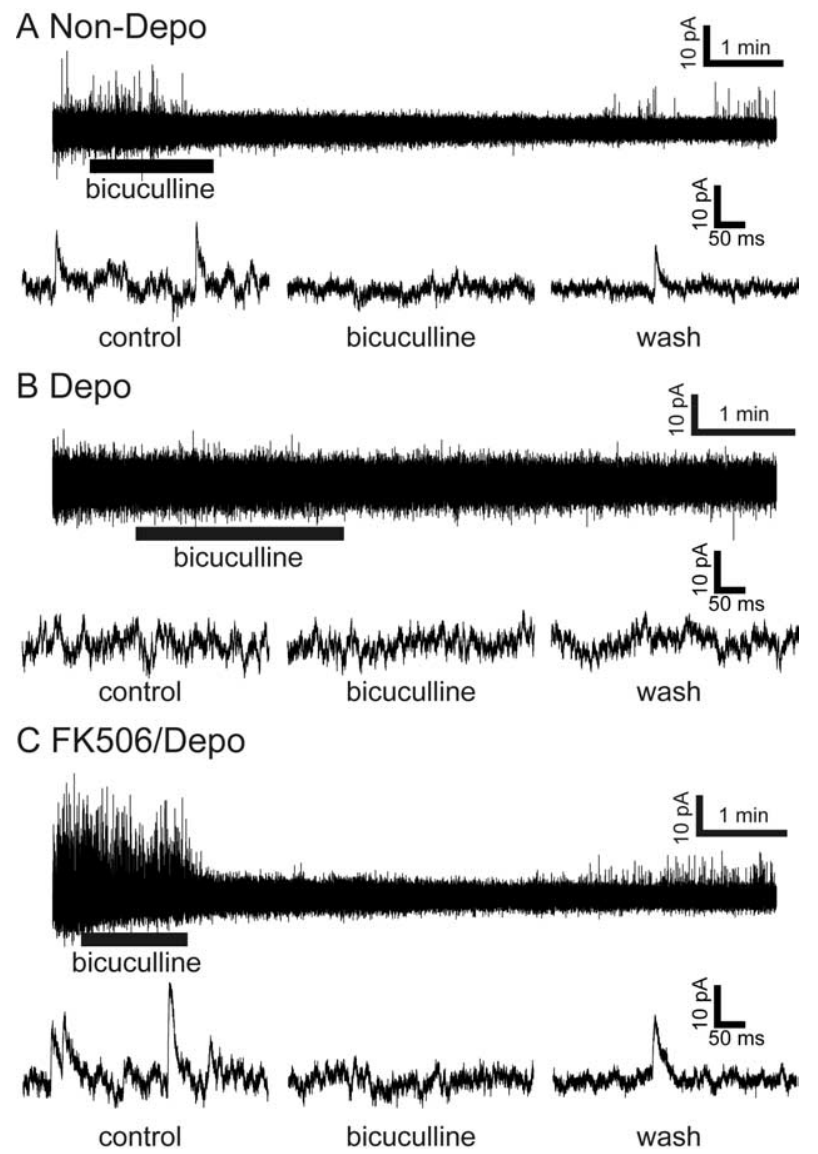

Figure 7. Recovery of GABAergic transmission by the addition of FK506 to depolarized granule cells. Granule cells were cultured at $5 \mathrm{~mm} \mathrm{KCl}(\boldsymbol{A})$ or $25 \mathrm{~mm} \mathrm{KCl}$ without (B) or with $(\boldsymbol{C}) 10 \mu \mathrm{m}$ FK506. Spontaneous IPSCs were recorded at the holding potential of $-20 \mathrm{mV}$ from granule cells at DIV 10 in the presence and absence of $20 \mu \mathrm{m}$ bicuculline methochloride. Representative current traces and an extended timescale of IPSCs are indicated in the top and bottom traces, respectively.

$\mu \mathrm{M}$ bicuculline methochloride ( $n=3$ of 3 ). The tonic inhibitory currents characteristic of the adult granule cells (Wall and Usowicz, 1997), however, was not detected in organotypic cultures. In contrast to granule cells cultured at low $\mathrm{KCl}$, granule cells depolarized with high $\mathrm{KCl}$ never showed any IPSCs $(n=7)$ (Fig. 7B). Remarkably, granule cells treated with FK506 at high $\mathrm{KCl}$ (three of four) exhibited IPSCs with a mean frequency of $1.47 \pm$ $1.15 \mathrm{~Hz}(n=3)$ and a mean amplitude of $21.1 \pm 1.3 \mathrm{pA}(n=13)$ (Fig. 7C). These currents were reversibly blocked by $20 \mu \mathrm{M}$ bicuculline methochloride ( $n=3$ of 3 ). These results demonstrate that the CaN signaling cascade plays a pivotal role in not only morphological maturation but also synaptic transmission of maturing granule cells.

\section{Discussion}

Neuronal cell development and maturation are hierarchically controlled by both extracellular signaling molecules and the intrinsic properties of neuronal cells. At the early postnatal period, many neuronal cells, including cerebellar granule cells, the lateral geniculate nucleus cells, and layer 1 cortical cells, exhibit the shift of the resting membrane potential from a depolarized state to a more hyperpolarized state (Ramoa and McCormick, 1994; Zhou and Hablitz, 1996; Rossi et al., 1998; Cathala et al., 2003). This investigation using GFP-expressing granule cells in organotypic cultures was thus directed at the regulatory role of alteration of 
the membrane potential in developing cerebellar granule cells. The ontogenic changes in the development and maturation of granule cells in organotypic cerebellar cultures were reported in several previous studies (Tanaka et al., 1994; Gähwiler et al., 1997; Dupont et al., 2006). In the present investigation, the detailed characterization of developmental and maturation processes of the granule cells were conducted by using several different approaches including morphology, immunostaining, and electrophysiology of defined GFP-positive granule cells. This characterization has explicitly indicated that granule cells develop and become mature in a temporally regulated manner under the physiological $\mathrm{KCl}$ concentration. The time-dependent changes in the developmental stages of the granule cells were easily identified and classified into four stages corresponding to those observed in vivo. According to this classification, the effect of membrane depolarization and its downstream $\mathrm{CaN}$ signaling were examined by culturing granule cells at high $\mathrm{KCl}$ with or without FK506. This analysis revealed that membrane depolarization had no effect on developmental processes of granule cells up to stage III but blocked the maturation processes leading to stage IV. These cells exposed to high $\mathrm{KCl}$ lacked the characteristic properties of mature granule cells such as a claw-like structure, expression and localization of mature synaptic proteins, and synaptic transmission. Importantly, the deficits resulting from membrane depolarization were all reversed by the addition of FK506 to cultures of the depolarized granule cells. The results have thus demonstrated that the shift to a hyperpolarized membrane potential and the resulting inactivation of $\mathrm{CaN}$ are essential for the maturation of postnatal granule cells.

Depolarization of dissociated granule cells in primary cultures has been proposed to mimic the activity-dependent maturation of granule cells by mossy fiber input (Gallo et al., 1987). However, the persistent depolarization of organotypically cultured granule cells abolished synaptic transmission and action potentials. Interestingly, the lack of action potentials and synaptic transmission was reported in dissociated granule cells exposed long term to high $\mathrm{KCl}$ (Mellor et al., 1998). The progressive hyperpolarization is thus critical for maturation of the intrinsic properties of granule cells in both primary cultures and organotypic cultures. It was reported that depolarization-induced $\mathrm{Ca}^{2+}$ entry upregulates the TASK-3 leak $\mathrm{K}^{+}$channel in dissociated granule cells, which in turn enhances the $\mathrm{K}^{+}$leak conductance and hyperpolarizes the resting membrane potential (Zanzouri et al., 2006). Although the knock-out mice deficient in the TASK-3 gene showed no obvious abnormality of their cerebellar architecture, nor impairments of cerebellar function, the leak $\mathrm{K}^{+}$channels evoked by at least five TASK-3-related genes in granule cells may play an important role in the transition of depolarized immature cells to their mature hyperpolarized state (Brickley et al., 2007).

The CaN signaling has been shown previously to be crucial in the regulation of gene expression implicated in the development and maturation of granule cells in primary cultures (Genazzani et al., 1999; Guerini et al., 2000; Li et al., 2000; Kramer et al., 2003; Suzuki et al., 2005; Zanzouri et al., 2006). In our previous studies, microarray analysis of cultured granule cells in combination with study of the gene expression pattern in vivo revealed that the activation of $\mathrm{CaN}$ by membrane depolarization induces many genes implicated in cell proliferation, differentiation, and migration of immature EGL granule cells, whereas inactivation of CaN predominantly upregulates genes involved in synaptic transmission and modulation of maturing IGL granule cells (Sato et al., 2005). In addition, it has been reported that the $\mathrm{GABA}_{\mathrm{A}} \alpha 6$ gene was highly expressed at low $\mathrm{KCl}$ but not at high $\mathrm{KCl}$ (Mellor et al.,
1998 ) with the $\mathrm{IC}_{50}$ just corresponding to the $\mathrm{IC}_{50}$ for the $\mathrm{KCl}$ induced blockade of granule cell maturation. Interestingly, cultures at high $\mathrm{KCl}$ for a certain period curtailed the ability to induce the $\mathrm{GABA}_{\mathrm{A}} \alpha 6$ expression on transfer to low $\mathrm{KCl}$ (Mellor et al., 1998). In the expression of the NR2C NMDA receptor, BDNF upregulated $\mathrm{NR} 2 \mathrm{C}$ at low $\mathrm{KCl}$ but not at high $\mathrm{KCl}$, and this blockade of NR2C upregulation was relieved by the inhibition of the CaN signaling cascade (Suzuki et al., 2005). Taking into consideration these observations, the present investigation strongly indicates that there is a critical temporal regulation of granule cell maturation and that the $\mathrm{CaN}$ signaling cascade plays a pivotal role in leading to terminal differentiation of granule cells. In further development of the cerebellum, a complex glomerular structure is formed, in which many granule cell dendrites surround a mossy fiber terminal and connect peripherally with Golgi cell axonal terminals. In the glomerular architecture, GABA spills out of synapses and activates extrasynaptic receptors (Wall and Usowicz, 1997). The bicuculline-sensitive inhibitory currents thus become tonic rather than action potential-dependent IPSCs. However, such tonic inhibition was not detected in stage IV granule cells of organotypic cultures probably because of the inability to form the complex glomerular architecture in organotypic cultures. It thus remains to be investigated whether the CaN signaling participates in the processes involved in the formation of the complex glomerular structure.

$\mathrm{CaN}$ signaling regulates several transcription factors and regulators (Shibasaki et al., 2002; Hogan et al., 2003). Recently, Shalizi et al. (2006) reported that the $\mathrm{Ca}^{2+}$-mediated activation of CaN dephosphorylates and in turn nonsumoylates a transcriptional repressor, myocyte enhancer factor 2A (MEF2A), in both organotypic cultures and in vivo analysis. Switching the unmodified MEF2A to the phosphorylated and sumoylated MEF2A then promotes dendritic claw differentiation of granule cells. This transcriptional repressor may thus serve as a key transcriptional regulator that controls the maturation program of granule cells. In addition, microarray analysis indicated that the inactivation of CaN influences many extracellular signaling molecules and transcriptional regulators in dissociated granule cell cultures (Sato et al., 2005). Furthermore, it has been shown that the signaling convergence of the CaN cascade and the BDNF-TrkB-Erk cascade is necessary for NR2C induction in the maturation process of granule cells in both cultured cells and in vivo (Suzuki et al., 2005). Thus, the CaN signaling plays a fundamental role in the terminal differentiation program of granule cells, but it is conceivable that the convergent and cross-talking mechanisms of the $\mathrm{CaN}$ cascade with other signaling cascades are involved in a variety of the terminal differentiation processes such as the expression and assembly of functional proteins and the synaptic organization of mature granule cells.

\section{References}

Brickley SG, Aller MI, Sandu C, Veale EL, Alder FG, Sambi H, Mathie A, Wisden W (2007) TASK-3 two-pore domain potassium channels enable sustained high-frequency firing in cerebellar granule neurons. J Neurosci 27:9329-9340.

Cathala L, Brickley S, Cull-Candy S, Farrant M (2003) Maturation of EPSCs and intrinsic membrane properties enhances precision at a cerebellar synapse. J Neurosci 23:6074-6085.

D’Angelo E, Rossi P, De Filippi G, Magistretti J, Taglietti V (1994) The relationship between synaptogenesis and expression of voltagedependent currents in cerebellar granule cells in situ. J Physiol Paris 88:197-207.

Dupont JL, Fourcaudot E, Beekenkamp H, Poulain B, Bossu JL (2006) Synaptic organization of the mouse cerebellar cortex in organotypic slice cultures. Cerebellum 5:243-256. 
Eccles JC, Ito M, Szentágothai J (1967) The mossy fiber input into the cerebellar cortex and its inhibitory control by Golgi cells. In: The cerebellum as a neuronal machine, pp 116-155. New York: Springer.

Gähwiler BH, Capogna M, Debanne D, McKinney RA, Thompson SM (1997) Organotypic slice cultures: a technique has come of age. Trends Neurosci 20:471-477.

Gallo V, Kingsbury A, Balázs R, Jørgensen OS (1987) The role of depolarization in the survival and differentiation of cerebellar granule cells in culture. J Neurosci 7:2203-2213.

Gaudillière B, Konishi Y, de la Iglesia N, Yao G, Bonni A (2004) A CaMKIINeuroD signaling pathway specifies dendritic morphogenesis. Neuron 41:229-241.

Genazzani AA, Carafoli E, Guerini D (1999) Calcineurin controls inositol 1,4,5-trisphosphate type 1 receptor expression in neurons. Proc Natl Acad Sci U S A 96:5797-5801.

Gu L, Li B, Yang X, Hu X, Huang X, Hertz L, Peng L (2007) Depolarizationinduced, glutamate receptor-mediated, and transactivation-dependent extracellular-signal regulated kinase phosphorylation in cultured cerebellar granule neurons. Neuroscience 147:342-353.

Guerini D, Wang X, Li L, Genazzani A, Carafoli E (2000) Calcineurin controls the expression of isoform $4 \mathrm{CII}$ of the plasma membrane $\mathrm{Ca}^{2+}$ pump in neurons. J Biol Chem 275:3706-3712.

Hogan PG, Chen L, Nardone J, Rao A (2003) Transcriptional regulation by calcium, calcineurin, and NFAT. Genes Dev 17:2205-2232.

Kadotani H, Hirano T, Masugi M, Nakamura K, Nakao K, Katsuki M, Nakanishi S (1996) Motor discoordination results from combined gene disruption of the NMDA receptor NR2A and NR2C subunits, but not from single disruption of the NR2A or NR2C subunit. J Neurosci 16:7859-7867.

Kramer D, Fresu L, Ashby DS, Freeman TC, Genazzani AA (2003) Calcineurin controls the expression of numerous genes in cerebellar granule cells. Mol Cell Neurosci 23:325-330.

Larramendi LMH (1969) Analysis of synaptogenesis in the cerebellum of the mouse. In: Neurobiology of cerebellar evolution and development (Llinas R, ed), pp 803-843. Chicago: American Medical Association.

León D, Sánchez-Nogueiro J, Marín-García P, Miras-Portugal MA (2008) Glutamate release and synapsin-I phosphorylation induced by $\mathrm{P}_{2} \mathrm{X}_{7}$ receptors activation in cerebellar granule neurons. Neurochem Int 52:1148-1159.

Li L, Guerini D, Carafoli E (2000) Calcineurin controls the transcription of $\mathrm{Na}^{+} / \mathrm{Ca}^{2+}$ exchanger isoforms in developing cerebellar neurons. J Biol Chem 275:20903-20910.

Liu J, Farmer JD Jr, Lane WS, Friedman J, Weissman I, Schreiber SL (1991) Calcineurin is a common target of cyclophilin-cyclosporin A and FKBPFK506 complexes. Cell 66:807-815.

Mellor JR, Merlo D, Jones A, Wisden W, Randall AD (1998) Mouse cerebellar granule cell differentiation: electrical activity regulates the $\mathrm{GABA}_{\mathrm{A}}$ receptor $\alpha 6$ subunit gene. J Neurosci 18:2822-2833.

Mundy WR, Robinette B, Radio NM, Freudenrich TM (2008) Protein biomarkers associated with growth and synaptogenesis in a cell culture model of neuronal development. Toxicology 249:220-229.

Nakanishi S, Okazawa M (2006) Membrane potential-regulated $\mathrm{Ca}^{2+}$ signalling in development and maturation of mammalian cerebellar granule cells. J Physiol 575:389-395.

Nusser Z, Sieghart W, Stephenson FA, Somogyi P (1996) The $\alpha 6$ subunit of the $\mathrm{GABA}_{\mathrm{A}}$ receptor is concentrated in both inhibitory and excitatory synapses on cerebellar granule cells. J Neurosci 16:103-114.
Okazawa M, Takao K, Hori A, Shiraki T, Matsumura K, Kobayashi S (2002) Ionic basis of cold receptors acting as thermostats. J Neurosci 22:3994-4001.

Ramoa AS, McCormick DA (1994) Developmental changes in electrophysiological properties of LGNd neurons during reorganization of retinogeniculate connections. J Neurosci 14:2089-2097.

Ramón y Cajal S (2000) Histogenesis of the cerebellum. In: Texture of the nervous system of man and the vertebrates, Vol II (Pasik P, Pasik T, translators and eds), pp 395-419. Vienna: Springer.

Rossi P, De Filippi G, Armano S, Taglietti V, D’Angelo E (1998) The weaver mutation causes a loss of inward rectifier current regulation in premigratory granule cells of the mouse cerebellum. J Neurosci 18:3537-3547.

Sato M, Suzuki K, Yamazaki H, Nakanishi S (2005) A pivotal role of calcineurin signaling in development and maturation of postnatal cerebellar granule cells. Proc Natl Acad Sci U S A 102:5874-5879.

Satoh S, Yanagita T, Maruta T, Nemoto T, Yoshikawa N, Kobayashi H, Tono T, Wada A (2008) Proteasomal degradation of IRS-2, but not IRS-1 by calcineurin inhibition: attenuation of insulin-like growth factor-Iinduced GSK-3 $\beta$ and ERK pathways in adrenal chromaffin cells. Neuropharmacology 55:71-79.

Shalizi A, Gaudillière B, Yuan Z, Stegmüller J, Shirogane T, Ge Q, Tan Y, Schulman B, Harper JW, Bonni A (2006) A calcium-regulated MEF2 sumoylation switch controls postsynaptic differentiation. Science 311:1012-1017.

Shibasaki F, Hallin U, Uchino H (2002) Calcineurin as a multifunctional regulator. J Biochem 131:1-15.

Shiraishi Y, Mizutani A, Yuasa S, Mikoshiba K, Furuichi T (2004) Differential expression of Homer family proteins in the developing mouse brain. J Comp Neurol 473:582-599.

Stoppini L, Buchs PA, Muller D (1991) A simple method for organotypic cultures of nervous tissue. J Neurosci Methods 37:173-182.

Stottmann RW, Rivas RJ (1998) Distribution of TAG-1 and synaptophysin in the developing cerebellar cortex: relationship to Purkinje cell dendritic development. J Comp Neurol 395:121-135.

Suzuki K, Sato M, Morishima Y, Nakanishi S (2005) Neuronal depolarization controls brain-derived neurotrophic factor-induced upregulation of NR2C NMDA receptor via calcineurin signaling. J Neurosci 25:9535-9543.

Tanaka M, Tomita A, Yoshida S, Yano M, Shimizu H (1994) Observation of the highly organized development of granule cells in rat cerebellar organotypic cultures. Brain Res 641:319-327.

Wall MJ, Usowicz MM (1997) Development of action potential-dependent and independent spontaneous $\mathrm{GABA}_{\mathrm{A}}$ receptor-mediated currents in granule cells of postnatal rat cerebellum. Eur J Neurosci 9:533-548.

West AE, Griffith EC, Greenberg ME (2002) Regulation of transcription factors by neuronal activity. Nat Rev Neurosci 3:921-931.

Xie F, Padival M, Siegel RE (2007) Association of PSD-95 with ErbB4 facilitates neuregulin signaling in cerebellar granule neurons in culture. J Neurochem 100:62-72.

Zanzouri M, Lauritzen I, Duprat F, Mazzuca M, Lesage F, Lazdunski M, Patel A (2006) Membrane potential-regulated transcription of the resting $\mathrm{K}^{+}$ conductance TASK-3 via the calcineurin pathway. J Biol Chem 281:28910-28918.

Zhou FM, Hablitz JJ (1996) Postnatal development of membrane properties of layer I neurons in rat neocortex. J Neurosci 16:1131-1139. 